
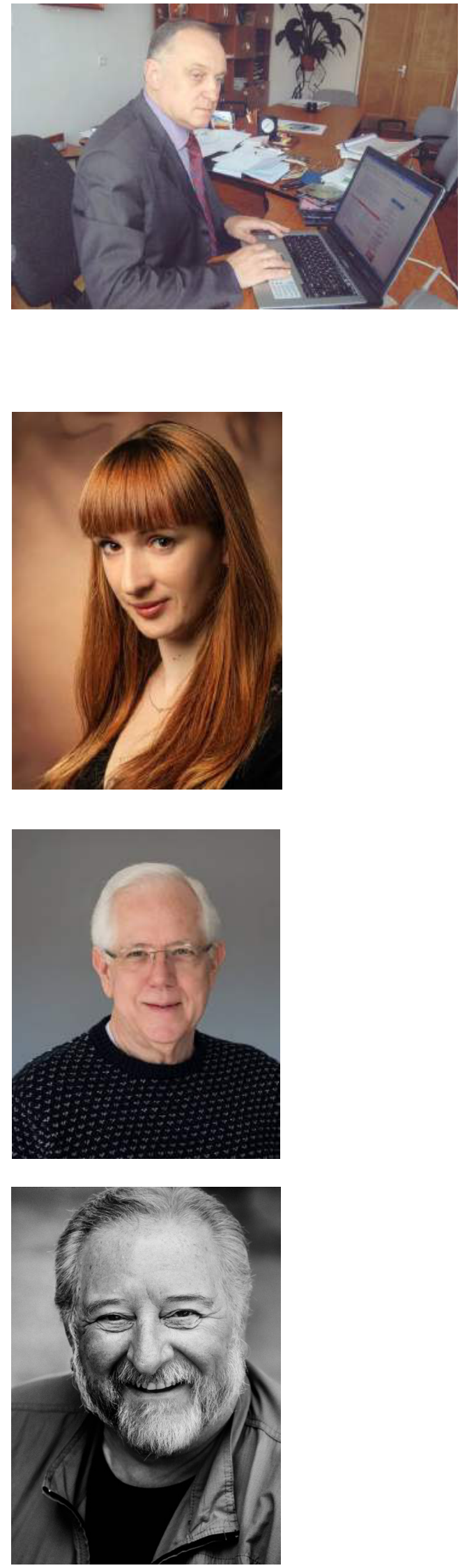

\section{Юрій Москаленко,}

кандидат фрілософських наук, професор, директор Івано-Франківського коледжу ДВНЗ «Прикарпатський національний університет імені Василя Стефраника» (м. Івано-Франківськ, Україна)

\section{Yuriy Moskalenko,}

Candidate of Philosophical Sciences, Professor, Director of Ivano-Frankivsk College of Vasyl Stefanyk Precarpathian National University (Ivano-Frankivsk, Ukraine) yurii.moskalenko@pu.if.ua

\section{Ганна Максимчук,}

кандидат педагогічних наук, викладач Івано-Франківського коледжу ДВНЗ «Прикарпатський національний університет імені Василя Стефаника» (м. Івано-Франківськ, Україна)

\section{Hanna Maksymchuk,}

Candidate of Pedagogical Sciences, Teacher of Ivano-Frankivsk college of Vasyl Stefanyk Prycarpathian National University (Ivano-Frankivsk, Ukraine) hannamaxymchuk@gmail.com

\section{Чарльз Ландрет,}

викладач тренінгів і семінарів, директор програми «Character International, Inc» (м. Даллас, штат Техас, США)

\section{Charles Landreth,}

Teacher Training Seminars,

Executive Director «Character International, Inc» (Dallas, Texas, USA)

\section{Джон Д. Кук,}

доктор психологічних наук, викладач тренінгів і семінарів, «Character International, Inc» (м. Даллас, штат Техас, США)

John D. Cooke,

$\mathrm{PhD}$, Teacher Training Seminars

«Character International, Inc»

(Dallas, Texas, USA) 


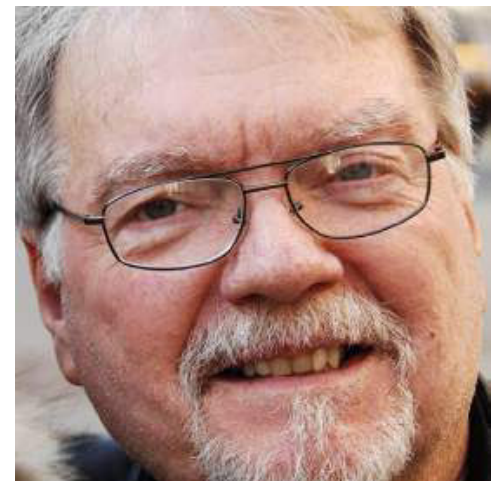

\section{Девід Ф. Глісон,}

сертифрікований тренер, магістр психології, викладач тренінгів і семінарів, «Character International, Inc» (м. Даллас, штат Техас, США)

\section{David Gleason,}

Teacher Training Seminars «Character International, Inc» (Dallas, Texas, USA)

Удк 159.922.7

\section{ФОРМУВАННЯ ХАРАКТЕРУ ДИТИНИ: ЗАПОЗИЧЕННЯ ДОСВІДУ США ДЛЯ УКРАЇНИ}

Анотація. У статті розкрито досвід формування характеру дитини у США, обґрунтовано співпрацю українських та американських викладачів щодо формування особистості майбутнього педагога, цінностей, які формують його характер та характер дітей, з котрими він працюватиме під час своєї професійної діяльності.

Ключові слова: «характер», «риси характеру», «моральні якості», «етичні принципи», «ціннісні орієнтації», «формування характеру дитини».

\section{CHARACTER FORMATION OF THE CHILD: PROMOTION OF THE US EXPERIENCE FOR UKRAINE}

Abstract. The article describes experience of forming the child's character in the USA, the cooperation between Ukrainian and American teachers regarding the formation of the personality of the future teacher, the values that shape his character and the character of children with whom he will work during his professional activity are substantiated.

Keywords: "character», "traits», «value orientations of the person», «moral qualities», «ethical principles», «formation of the child's character».

\section{ВСТУП}

Постановка проблеми. Реформування системи освіти в Україні, ухвалення концепції «Нової української школи» передбачає проведення докорінної та системної перебудови загальної середньої освіти, створення умов для зміни початкової освіти з урахуванням досвіду провідних країн світу [4]. Зокрема, нові стандарти змісту загальної середньої освіти, що ґрунтуються на компетентнісному та особистісно орієнтованому підході до навчання, передбачають також стимулювання особистого і професійного зростання педагога.

«Великі проблеми, які $є$ перед нами, не можна вирішити на тому ж рівні мислення, на якому були ми, коли виникали ці проблеми» (А. Енштейн). Важливим фрактором у реформуванні освіти є також і зміна вектора, налагодження діалогу та взаємодії між учителем та учнем, урахування насамперед психічних особливостей дитини (ії̈ здібностей, характеру, інтересів тощо) у навчально-виховному процесі. Система початкової ланки освіти в Україні потребує абсолютно нового підходу до навчання молодших школярів, формування у них рис характеру, особистісних якостей, адже неможливо навчати сучасних дітей так, як навчали нас.

Саме тому важливо дослідити, як педагоги США співпрацюють з дітьми і як формують у них риси характеру, як здійснюється фрахова методична підготовка студентів до такої роботи у педагогічних вищих навчальних закладах.

Аналіз останніх досліджень і публікацій. Формування характеру дитини є досить складним і неоднозначним процесом, щодо бачення якого склалися різні погляди та підходи. Серед найбільш продуктивних слід назвати аксіологічний (О. Александрова, Н. Асташова, В. Бездухов, Г. Бурцева, О. Власенко, Б. Гершунський, 3. Демченко, В. Денисенко, В. Зінченко, А. Кирьякова, В. Король, О. Кузнецова, В. Сластьонін, В. Семиченко, Р. Скульський, $€$. Шиянов та ін.); діяльнісний (Б. Ананьєв, Г. Балл, Л. Виготський, В. Давидов, Г. Костюк, О. Леонтьєв, С. Рубінштейн та ін.); особистісно орієнтований (Г. Балл, І. Бех, Л. Виготський, І. Зязюн, О. Киричук, Г. Костюк, М. Красовицький, О. Леонтьєв, А. Маслоу, К. Роджерс, Л. Рубінштейн, В. Серіков, В. Сухомлинський, О. Сухомлинська та ін.); компетентнісний (В. Байденко, Н. Бібік, Е. Зеєр, О. Овчарук, О. Пометун, І. Родигіна, А. Хуторськой та ін.).

МЕТА І ЗАВДАННЯ ДОСЛІДЖЕННЯ - проаналізувати методологію, теоретичні концепції та практичний досвід США у напрямі формування характеру дитини молодшого шкільного віку з боку педагога для удосконалення системи освіти в Україні.

МЕТОДИ ДОСлІДЖЕНнЯ: аналіз наукової літератури з проблеми фрормування характеру дитини, вивчення досвіду науковців зі США.

РЕЗУЛЬТАТИ ДОСЛІДЖЕННЯ

Характер дитини - це своєрідна, неповторна, душевна людська природа, яка фрормується ще з немовлячого віку серед людей у тісній взаємодії з ними. 
Характер людини розвивається поступово протягом багатьох років навчання та практичного використання знань у щоденному житті. Такі цінності характеру, як чесність, надійність, повага, відповідальність, турбота, сміливість і справедливість, починають формуватися в процесі виховання батьками своєї дитини. Коли дитина починає відвідувати школу, до процесу фрормування її характеру долучаються і вчителі. Вони є прикладом для наслідування, взірцем, професіоналами, що володіють різноманітними методами та прийомами навчання і виховання.

Як зазначає І. Бех, формування рис характеру дитини має надзвичайно важливе значення, адже завдяки своїм сутнісним показникам вони можуть виконувати функцію вищого критерію для орієнтації індивіда в світі й опори для особистісного самовизначення $[1$, с. 6]. Шлях фрормування характеру, як підкреслює дослідник, має полягати у сходженні від конкретного до загального. Це означає, що, наприклад, повагу до людства можна виховати в дитини, якщо спочатку в неї формується це ставлення до близької їй людини, далі - до оточуючих людей, а згодом це коло може збільшуватися. Розширення сфери цінностей слід розглядати як процес дедалі більшої диференціації сфери власне людського ставлення до світу [1, с. 13-14].

О. Леонтьєв вважає, що фрормування характеру відбувається через засвоєння людиною суспільно значущих цінностей, нормативів та установок. Зокрема, вчений розробив положення про те, що індивідуальне буття особистості відбувається через внутрішню позицію, через становлення особистісних смислів, які визначають індивідуальні варіанти характеру. У цьому випадку засвоєні людиною значення, обумовлені її потребами, інтересами і зафріксовані в установках, складаються в ціннісні орієнтації як конкретне ставлення до цінностей життя [3].

Ще одним із важливих чинників, який впливає на фрормування характеру дитини, як зазначають В. Сухомлинський, Н. Волкова, М. Євтух, Н. Кузьміна, В. Сластьонін та ін., є особистість самого вчителя. Учитель у системі гуманістичної психології повинен мати необхідні професійно значущі якості, не мати авторитарно-імперативних установок, визнавати унікальність особистості учня. Дослідники вказують на важливість відмови від авторитарноімперативного підходу до вирішення професійно-педагогічних завдань. Першочергового значення вони надають емпатійному сприйняттю особистості дитини, «фасилітації» навчального процесу, гнучкості, креативності, здатності вчителя до самоактуалізації, діалогічності у спілкуванні, його прагненню до самовдосконалення.

Так, В. Сухомлинський стверджує, що одним із важливих виховних завдань учителя є те, щоб діти зрозуміли і відчули серцем: завдяки створенню матеріальних і духовних благ визначається у нашому суспільстві ставлення людини до людини, суспільне обличчя громадянина. Педагог був переконаний, що формування характеру особистості залежить від середовища, у якому здійснюється цей процес. Домінування у ньому моральних цінностей, культура спілкування, толерантність, розуміння потреб дитини - ось важливі складові взаємодії з дитиною [5].

У формуванні характеру дитини, на думку науковців США, першочерговим завданням $є$ навчити цих ключових цінностей учителів, які надалі повинні стати для учнів взірцем для наслідування. Щоб прищепити ці цінності своїм учням, учителі у школі застосовують різні методи, залежно від віку учнів. Таке навчання відбувається кожного дня, коли діти взаємодіють із оточенням у школі та вдома і пізнають, що є допустимим і недопустимим, правильним і неправильним, хорошим і поганим. Надзвичайно важливо, щоб учителі в повсякденному житті самі керувалися тими цінностями, які вони хочуть розвивати у дітей. Читаючи книжки, граючи в ігри та працюючи на заняттях, учні бачать приклади того, що означає мати хороший характер [2].

У міру свого зростання діти випробовують цю систему цінностей і піддають ії̈ ретельній перевірці. Тому вкрай важливо, щоб їхній моральний розвиток під керівництвом учителів і батьків тривав протягом усього часу, поки вони не стануть незалежними. Кінця цьому навчанню немає, тому що навіть у дорослому віці ми схильні приймати погані рішення. Ми повинні постійно оцінювати і перевіряти себе.

У практиці та досвіді США фрормування характеру здійснюється через залучення до цього процесу також батьків і громадськості. Так, на думку автора програми «Character International, Inc» Лінди Ландрет, залучення батьків до процесу виховання надзвичайно важливе. Учителям варто зустрітися із батьками своїх учнів, розповісти їм про виховання характеру дітей і попросити їх сприяти закріпленню цінностей, щомісяця виконуючи завдання, передбачені для сімейної роботи. Посібник з розвитку характеру, що надсилають додому, закликає батьків долучитися до участі в цьому навчанні всією родиною. Ці рекомендації щодо розвитку високих моральних цінностей не тільки допомагають формувати характер, а й сприяють розвитку гармонійних стосунків між батьками та дітьми [2].

Залучення громадськості до формування характеру дитини здійснюється через підтримку представників бізнесу та місцевої влади. Так, американські дослідники пропонують, наприклад, щомісяця розповсюджувати буклети і брошури, в яких пропагуються високі цінності. Демонструючи у своєму житті чесність, надійність, повагу, відповідальність, турботу, сміливість і справедливість, представники влади і бізнесу також можуть стати членами команди. Таким чином, уся громада бере на себе відповідальність за розвиток і підтримку своєї молоді. Яка від цього користь? Компанії, органи влади та інші установи отримають чесних, надійних і далекоглядних працівників. Це буде нове покоління людей з високими моральними якостями.

Можливість перейняти досвід щодо формування характеру дитини у науковців США з'явилася в українських викладачів та студентів ще весною 2015 року. Саме у цей час було підписано угоду між Івано-Франківським коледжем ДВНЗ «Прикарпатський національний університет імені Василя Стефаника» і програмою «Сharacter International, Inc». Підписанням угоди передбачено міжнародну співпрацю у сфері освіти на п'ять років. Iї̈ метою $€$ проведення семінарів і тренінгів щодо фрормування характеру дитини як для студентів, так і для викладачів коледжу. Тренерами є викладачі США (штат Техас): доктор психологічних наук Джон Д. Кук та сертифікований тренер, магістр психології Девід Ф. Глісон. 
Програма складається із трьох рівнів, кожному з яких присвячений окремий тренінг: «Виховання характеру дітей», «Конфлікти. Стратегії, способи виходу із конфліктних ситуацій», «Лідерство».

Цікавими є самі форми викладання інформації іноземними викладачами. Це демонстрування доступних для розуміння кожним студентом презентацій, власних прикладів з життя, історій про види дитячого характеру. Це інтерактивні та ігрові форми роботи, інсценування.

Тренінг «Виховання характеру дітей» $є$ своєрідним першим етапом ознайомлення із характером дитини студентів і викладачів. Після його відвідування студенти дізнаються про сутність поняття «характер», його риси та основні компоненти, загальнолюдські цінності, хороші та погані звички, моральні якості. Для ефективнішої роботи студенти працюють із підручником «Виховання характеру дітей», автором якого є Лінда Ландрет. Підручник написаний українською та англійською мовами, що дає можливість студентам самостійно опрацьовувати його.

Тренінг «Конфрлікти. Стратегії, способи виходу із конфліктних ситуацій» ознайомлює слухачів із поняттям «конфлікт», стратегіями поведінки у конфлікті, основними шляхами виходу із конфліктних ситуацій, які виникають у школі та повсякденному житті. Під час тренінгу студенти ознайомлюються із методикою роботи з конфліктами, вчаться формувати в учнів уміння вирішувати різного роду суперечки.

Тренінг «Лідерство» вчить виховувати учнів справжніми лідерами, формувати в них особистісні лідерські якості та уміння.

Після кожного із тренінгів слухачі отримують відповідні сертифікати. Студенти та викладачі, котрі проходять усі три рівні навчання, отримають додатковий сертифрікат тренера, і це дозволяє проводити тренінг відповідної тематики.

За час співпраці 161 студент спеціальностей «Початкова освіта» та «Дошкільна освіта» і троє викладачів пройшли усі три рівні навчання та отримали сертифікати тренерів. Два етапи навчання пройшли 109 студентів нашого коледжу та восьмеро викладачів, перший етап - 76 студентів.

Студенти приємно вражені манерою навчання американських викладачів. Лекції проводяться англійською мовою. Для студентів, які вивчають іншу іноземну мову, працює перекладач, яка передає не лише зміст викладеного, а й емоції заокеанських колег.

Щоб забезпечити якість надання студентам знань із психології, на базі коледжу створено Творчу лабораторію з вивчення та формування характеру дитини, Асоціацію психологів «Character International, Inc.», сайт асоціації. На сайті розміщено інформацію про навчальні тренінги, публікації студентів, відгуки про семінари.

ВИСНОВКИ ТА ПЕРСПЕКТИВИ ПОДАЛЬШИХ ДОСЛІДЖЕНЬ

3 метою і надалі переймати досвід американських науковців щодо формування характеру дитини заплановано проведення спільних конференцій для викладачів, спільні наукові публікації, взаємовідвідування занять викладачами та студентами у межах Програми дослідження.

«Посієш вчинок - пожнеш звичку, посієш звичку - пожнеш характер, посієш характер - пожнеш долю». (Народне прислів'я).

\section{СПИСОК ВИКОРИСТАНИХ ДЖЕРЕЛ}

[1] Бех І. Виховання особистості : у 2 кн. К. : Либідь, 2003. Кн. 1 : Особистісно орієнтований підхід: теоретико-технологічні засади. 280 с.

[2] Ландрет Л. Виховання характеру дітей. Навчальна програма для вчителів / пер. з англ. Степанова В. ВБФ «Східноєвропейська гуманітарна місія», 2015. 112 с.

[3] Леонтьев А. Психология общения. 2-е изд. М. : Смысл, 1997. 365 с.

[4] Нова українська школа: концептуальні засади реформування середньої школи. URL : http://mon.gov.ua/\%D0\%9D\%D0\%BE \%D0\%B2\%D0\%B8\%D0\%BD\%D0\%B8\%202016/12/05/konczepcziya.pdf

[5] Сухомлинський В. Батьківська педагогіка. К.: Рад. школа, 1978. 263 с.

\section{REFERENCES (TRANSLATED AND TRANSLITERATED)}

[1] Bekh I. Vykhovannja osobystosti (Parenting): u 2 kn. K. : Lybidj, 2003. Kn. 1 : Osobystisno orijentovanyj pidkhid: teoretykotekhnologhichni zasady. $280 \mathrm{~s}$. (in Ukrainian)

[2] Landret L. Vykhovannja kharakteru ditej. Navchaljna proghrama dlja vchyteliv (Child upbringing. Teaching curriculum) / per. z anghl. Stepanova V. VBF «Skhidnojevropejsjka ghumanitarna misija», 2015. $112 \mathrm{~s}$. (in Ukrainian)

[3] Leontj'ev A. Psykhologhyja obshhenyja (Psychology of communication). 2-e yzd. M. : Smbsl, 1997. 365 s. (in Russian)

[4] Nova ukrajinsjka shkola: konceptualjni zasady reformuvannja serednjoji shkoly (New Ukrainian School: Conceptual Principles for Reforming the Secondary School). URL : http://mon.gov.ua/\%D0\%9D\%D0\%BE\%D0\%B2\%D0\%B8\%D0\%BD\%D0\%B8\%20 2016/12/05/konczepcziya.pdf (in Ukrainian)

[5] Sukhomlynsjkyj V. Batjkivsjka pedaghoghika (Parent Pedagogy). K.: Rad. shkola, 1978. 263 s. (in Ukrainian)

\section{*LETTER OF THANKS}

The Administration of Ivano-Frankivsk College State HigherEducational Institution "Vasyl Stefanyk Precarpathian National University» express deep gratitude to Trainers of "Character International, Inc., (Texas) for fruitful cooperation and valuable experience for teachers and students in the field of child character formation. The program has been already implemented in our institution education for three years and has its visible results. In particular more than 300 students specialties "Primary Education» and «Preschool Education» have already passed their training and got certificates; most of them conduct basic and in-depth trainings and seminars by themselves, put their acquired knowledge into practice, have their projects on child character formation themes, participate in scientific conferences, also perform individual tasks and report at online meetings during inter-sessional period. 